\title{
Modulatory effects of levamisole and garlic oil on the immune response of Wistar rats: Biochemical, immunohistochemical, molecular and immunological study
}

\author{
ESSAM HASSAN MOHAMED ${ }^{1}$, AHMED ABDEL-AZIZ BAIOMY ${ }^{2,3}$, \\ ZEIN SHABAN IBRAHIM ${ }^{4,5}$ and MOHAMED MOHAMED SOLIMAN ${ }^{3,6}$
}

\begin{abstract}
${ }^{1}$ Department of Bacteriology, Mycology and Immunology, Faculty of Veterinary Medicine, Zagazig University, Zagazig 44519;
${ }^{2}$ Department of Zoology, Faculty of Science, Cairo University, Giza 12613, Egypt; ${ }^{3}$ Department of Medical Laboratories, Faculty of Applied Medical Sciences, Taif University, Turabah 21974; ${ }^{4}$ Department of Physiology, College of Medicine, Taif University, Taif 21944, Saudi Arabia; ${ }^{5}$ Department of Physiology, Faculty of Veterinary Medicine, Kafrelsheikh University, Kafr El-Sheikh 33516; ${ }^{6}$ Department of Biochemistry, Faculty of Veterinary

Medicine, Benha University, Moshtohor 13511, Egypt
\end{abstract}

Received March 2, 2016; Accepted June 20, 2016

DOI: $10.3892 / \mathrm{mmr} .2016 .5551$

\begin{abstract}
Levamisole (LEVA) and garlic are prevalent immunomodulators in humans and animals. Therefore, the present study aimed to examine the immunomodulatory effects of LEVA and garlic oil (GO) alone or in combination on the immune response of Wistar rats. A total of 24 male Wistar rats were allocated into four equal groups: Control group, which was given ad libitum access to food and water; and groups 2-4, which were orally administered LEVA $[2.5 \mathrm{mg} / \mathrm{kg}$ body weight (BW) every 2 days], GO, ( $5 \mathrm{ml} / \mathrm{kg}$ BW daily), or LEVA plus GO, respectively for 4 consecutive weeks. Serum immunoglobulin (Ig)G and IgM levels were measured using a radial immunodiffusion assay. Serum cytokine levels, including interferon (IFN) $-\gamma$, interleukin (IL)-5 and tumor necrosis factor (TNF)- $\alpha$, were measured using enzyme-linked immunosorbent assay kits. Total blood counts were measured automatically using a cell counter. Serum lysozyme enzymatic activity was determined by measuring the diameters of the zones of clearance relative to lysozyme. Immunohistochemical detection of CD4 and CD8 was carried out using the streptavidin-biotinperoxidase method. Furthermore, the mRNA expression levels of IL-4, IL-5 and IL-12 were measured in the leukocytes and thymus gland by semi-quantitative polymerase chain reaction. The results revealed that LEVA increased serum levels of IFN- $\gamma$, IL-5 and TNF- $\alpha$ cytokines, whereas co-administration of LEVA and GO decreased the stimulatory action of LEVA alone. LEVA and GO alone increased the serum levels of IgG,
\end{abstract}

Correspondence to: Professor Mohamed Mohamed Soliman, Department of Biochemistry, Faculty of Veterinary Medicine, Benha University, Al-Canal Street, Moshtohor 13511, Egypt

E-mail: mohamed.soliman@fvtm.bu.edu.eg

Key words: levamisole, garlic oil, immune effects, Wistar rats
IgM and total blood cell counts, and co-administration of GO and LEVA inhibited the effects of LEVA. At the cellular level, in the spleen, LEVA increased immunoreactivity of CD4 and CD8, whereas co-administration of GO with LEVA decreased this strong expression. At the molecular level, in leukocytes, LEVA upregulated the mRNA expression levels of IL-2, IL-4 and IL-5, whereas GO alone downregulated mRNA expression. Co-administration of GO with LEVA inhibited the LEVA-induced upregulation of IL-2, IL-4 and IL-5 mRNA expression. In the thymus, both LEVA and GO upregulated the mRNA expression levels of IL-4 and IL-5, whereas LEVA alone did not affect IL-12 mRNA expression. Co-administration of GO with LEVA inhibited LEVA-induced upregulation of IL-4 and GO-induced upregulation of IL-12 expression, and had an additive upregulatory effect on IL-5 expression. In conclusion, LEVA stimulated T-helper (Th)1 cytokines, whereas GO stimulated a Th2 response, and co-administration of $\mathrm{GO}$ with LEVA inhibited the stimulatory effects of LEVA and balanced the Th1/Th2 response.

\section{Introduction}

The immune system provides the host with defense against foreign antigens, and ensures limiting activation against self-antigens during immune surveillance (1). Immunomodulation either stimulates or suppresses the host immune system, in order to enable it to succeed against perturbing conditions. Immunomodulators are biological agents that improve the host defense mechanism against disease, by striking a balance between regulatory and effector cells (2). Nutrients and other spice constituents have the potential to affect almost all aspects of the immune system (3).

Garlic (Allium sativum) is a member of the lily family, which has been widely used as an ancient folk medicine in India, Egypt, Greece, Rome and China to treat various sicknesses, including abdominal pain, parasitic infections and rheumatism (4). Its high vitamin $\mathrm{C}$ content and antimicrobial properties make it 
a significant and potent immune system booster. In addition, it is very effective against bacterial, viral, fungal and parasitic infections (5). Garlic enhances various immune factors, such as macrophage and T-lymphocyte phagocytic activities (6). The immunomodulatory effects of garlic are due to garlic lectin or agglutinin proteins (7). In a previous study, protein fractions purified from fresh garlic bulbs were reported to augment $\mathrm{CD}^{+} \mathrm{T}$-cell infiltration into the tumor site and inhibit tumor growth (8).

Levamisole (LEVA) is a synthetic broad-spectrum anthelmintic widely used in veterinary practice. LEVA has attracted attention due to its use as an immunomodulator, and it has been shown to support anti-carcinogenic activity in skin diseases and improve weight gain in animals $(9,10)$. In some countries, LEVA is used as an immunomodulatory agent to treat human cancer (11).

LEVA is able to modulate the immune system by resetting the immune balance towards a $\mathrm{T}$ helper $(\mathrm{Th}) 1$ response $(11,12)$. It has been reported to reconstitute the histological integrity of the thymus in malnutrition (13). Furthermore, its influence on the course of allergic diseases has been demonstrated to cause a shift from Th2-dominant immunity towards a Th1-mediated response in $\mathrm{BALB} / \mathrm{c}$ mice (14). LEVA has been reported to induce sufficient dendritic cell maturation, in order to promote the activation of naïve $\mathrm{T}$ cells toward a Th1 response (15). LEVA has also been reported to increase serum complement activity and leukocyte functions, including phagocytosis and/or lymphokine production by lymphocytes (16). LEVA-induced suppression of the Th2 immune response and stimulation of the Th1 immune response are clinically important in the prevention and treatment of atopic diseases (17). LEVA stimulates the production of several cytokines, including interferon (IFN)- $\gamma$, interleukin (IL)-6, IL-12, IL-18 and IL-1 $(12,15)$. The immunohistochemical study of CD4 and CD8 is important; however, few studies have been conducted.

The present study aimed to investigate the biochemical, immunohistochemical and molecular effects of garlic extract and LEVA alone or in combination on the immune response in Wistar rats.

\section{Materials and methods}

Chemicals and kits. LEVA, ethidium bromide and agarose were purchased from Sigma-Aldrich (St. Louis, MO, USA). The Wistar rats were purchased from King Fahd Center for Scientific Research (King Abdel-Aziz University, Jeddah, Saudi Arabia). Serologic mouse interferon gamma (cat. no. MBS289298), IL-5 (mouse) (cat. no. MBS260096) and rat TNF-alpha (cat. no. MBS2882073) enzyme-linked immunosorbent assay (ELISA) kits were purchased from My Biosource, Inc. (San Diego, CA, USA). The DNA 100 bp ladder was purchased from Fermentas (Thermo Fisher Scientific, Inc., Waltham, MA, USA). QIAzol for RNA extraction and oligo dT primers were purchased from Qiagen, Inc. (Valencia, CA, USA). Anti-rat CD4 (cat. no. sc-7219) and CD8 (cat. no. sc-18860) primary antibodies were purchased from Santa Cruz Biotechnology, Inc. (Dallas, TX, USA).

Animals, experimental design and sampling. All animal procedures were approved by the Ethical Committee Office of the dean of scientific affairs of Taif University (Taif, Saudi Arabia). A total of 24 male Wistar rats (age, 3 months; weight, 200-280 g) were used in the present study. For acclimation, the rats were handled daily and kept under observation for 1 week prior to onset of the experiment. The rats were maintained under a 12-h light-dark cycle, and were given ad libitum access to food and water. The 24 rats were divided into four groups ( $\mathrm{n}=6 / \mathrm{group}$ ): Control group, which received only corn oil as treatment; LEVA group, which were orally administered LEVA [2.5 mg/kg body weight (BW)] every 2 days for 4 weeks; garlic oil (GO; Sigma-Aldrich) group, which were orally administered GO (5 ml/kg BW) daily for 4 weeks (18); and the LEVA plus GO group, which were administered LEVA and GO (5 ml GO plus $2.5 \mathrm{mg} / \mathrm{kg}$ BW LEVA) for 4 weeks.

A total of $24 \mathrm{~h}$ after administration of the final medication, all rats were sacrificed following anesthetization by diethyl ether inhalation. Blood samples were subsequently taken from the medial canthus of the eye. The rat heads were then dislocated, and tissue samples were collected under sterile conditions. Serum samples were extracted following centrifugation of the blood at $4,000 \mathrm{x}$ for $10 \mathrm{~min}$ at $4{ }^{\circ} \mathrm{C}$. For gene expression analysis, thymus tissues and blood samples were maintained in QIAzol reagent at $-80^{\circ} \mathrm{C}$ for RNA extraction. Spleen samples were maintained in $10 \%$ neutral buffered formalin (NBF) at room temperature for $24 \mathrm{~h}$ for histopathological and immunohistochemical analysis.

Serum cytokine and immunoglobulin (Ig) assays. IgG and IgM were measured in the serum samples obtained from rats using a radial immunodiffusion assay purchased from First Clinical Laboratory (Cairo, Egypt). Levels of the following serum cytokines: IFN- $\gamma$, IL-5 and tumor necrosis factor (TNF)- $\alpha$ were measured using ELISA kits, according to the manufacturer's protocols.

Total blood counts and lysozyme activity. Total blood counts of EDTA blood were measured automatically using a cell counter set (Bio-Rad Laboratories Inc., Hercules, CA, USA). Lysozyme enzymatic activity in the serum samples was determined by measuring the diameters of the zones of clearance relative to lysozyme (19).

Histological examination. Samples for histological examination were taken from the spleen, were fixed in $10 \%$ NBF solution, washed in tap water, dehydrated using various grades of alcohol, cleared using xylene, and embedded in paraffin. The paraffin-embedded tissue blocks were cut into $5 \mu \mathrm{m}$ sections. The sections were then routinely stained with hematoxylin and eosin (20). Tissue slides were visualized using a Wolfe S9-0982 microscope (Carolina Biological Supply Co., Burlington, NC, USA) and images were captured using a Canon Power Shot SX500 IS digital camera (Canon, Inc., Tokyo, Japan).

Immunohistochemistry. Immunohistochemical reactions were carried out using the streptavidin-biotin-peroxidase method. Primary antibodies against CD4 and CD8 (Santa Cruz Biotechnology, Inc.) were diluted to 1:500 in phosphate-buffered saline (PBS). As positive controls, normal tissue (spleen and/or thymus) was tested for CD4 and CD8. 
Spleen sections were deparaffinized in xylene, washed in PBS ( $\mathrm{pH}$ 7.4), and rehydrated in a graded series of ethanol solutions. Endogenous peroxidase activity was blocked following incubation with $3 \%$ hydrogen peroxide in methanol for $10 \mathrm{~min}$. After washing in PBS, the specimens were saturated with $10 \%$ normal goat serum (Histofine SAB-PO kit; Nichirei Corporation) for $5 \mathrm{~min}$ and were incubated at room temperature for $30 \mathrm{~min}$ with the primary antibodies. After washing in PBS, the slides were incubated with biotinylated goat anti-mouse Ig antibody (Histofine SAB-PO kit; Nichirei Corporation) for $60 \mathrm{~min}$ at room temperature. Immunohistochemical reactions were visualized using freshly prepared 3,3 $\beta$-diaminobenzidine tetrahydrochloride (Histofine SAB-PO kit; Nichirei Corporation). Subsequently, slides were counterstained with hematoxylin and were mounted on coverslips (21). Tissue slides were visualized using a Wolfe S9-0982 microscope and images were captured using a Canon Power Shot SX500 IS digital camera.

RNA extraction, cDNA synthesis and semi-quantitative polymerase chain reaction $(P C R)$ analysis. All rats were anesthetized by diethyl ether inhalation until they lost consciousness. Subsequently, blood samples were taken from the medial canthus of the eye. Total RNA was extracted from the thymus as previously discussed (22). For leukocyte RNA extraction, $1 \mathrm{ml}$ QIAzol was added to $350 \mathrm{ml}$ total blood collected in tubes containing an anticoagulant. RNA concentration and purity were determined spectrophotometrically by measuring optical density at 260 and $280 \mathrm{~nm}$. RNA integrity was confirmed after running on a $1.5 \%$ denatured agarose gel stained with ethidium bromide. The ratio of 260/280 optical density of all RNA samples was 1.7-1.9. A mixture of $3 \mu \mathrm{g}$ total RNA and $0.5 \mathrm{ng}$ oligo dT primer was used for cDNA synthesis, in a total volume of $11 \mu \mathrm{l}$ sterilized DEPC water. The mixture was incubated in a Bio-Rad T100 ${ }^{\mathrm{TM}}$ Thermal Cycler (Bio-Rad Laboratories, Inc.) at $65^{\circ} \mathrm{C}$ for $10 \mathrm{~min}$ for denaturation. Subsequently, $2 \mu 110 \mathrm{X}$ reverse transcription-buffer, $2 \mu 110 \mathrm{mM}$ dNTPs and 100 units Moloney Murine Leukemia Virus Reverse Transcriptase (SibEnzyme Ltd., Novosibirsk, Russia) were added, and the total volume was made up to $20 \mu \mathrm{l}$ using DEPC water. The mixture was then re-incubated in the Bio-Rad thermal cycler at $37^{\circ} \mathrm{C}$ for $1 \mathrm{~h}$, and at $90^{\circ} \mathrm{C}$ for $10 \mathrm{~min}$ in order to inactivate the enzyme. For semi-quantitative PCR analysis, specific primers for the examined genes (Table I) were designed using Oligo-4 computer program and were synthesized by Macrogen (Macrogen Inc., Seoul, Korea). PCR was conducted in a final volume of $25 \mu \mathrm{l}$, which consisted of $1 \mu \mathrm{lDNA}, 1 \mu \mathrm{l} 10 \mathrm{pM}$ of each primer (forward and reverse), and 12.5 $\mu$ l PCR master mix (Promega Corporation, Madison, WI, USA); the volume was brought up to $25 \mu \mathrm{l}$ using sterilized, deionized water. PCR was carried out using the Bio-Rad $\mathrm{T}_{100}{ }^{\mathrm{TM}}$ Thermal Cycler, and the cycling conditions were as follows: One cycle at $94^{\circ} \mathrm{C}$ for $5 \mathrm{~min}$, followed by 27 cycles (Table I), each of which consisted of denaturation at $94^{\circ} \mathrm{C}$ for $1 \mathrm{~min}$, annealing at the specific temperature corresponding to each primer, and extension at $72^{\circ} \mathrm{C}$ for $1 \mathrm{~min}$, with an additional final extension step at $72^{\circ} \mathrm{C}$ for $7 \mathrm{~min}$. As a reference, expression of glyceraldehyde-3-phosphate dehydrogenase (G3PDH) mRNA was examined. PCR products were visualized under UV light following 1.5\% agarose gel electrophoresis (Bio
Basic Inc., Markham, ON, Canada). The gel was stained with ethidium bromide in Tris-Borate-EDTA buffer. Images of the PCR products were captured using a gel documentation system (GelDoc-It Imaging system; UVP, LLC, Upland, CA, USA). The intensity of the bands was quantified densitometrically using ImageJ software version 1.47 (http://imagej.en.softonic. $\mathrm{com} /)$.

Statistical analysis. Results are presented as the mean \pm standard error of the mean. Data were analyzed using one-way analysis of variance followed by the least significant difference test for multiple comparisons among groups. Statistical analysis was conducted using SPSS software version 11.5 for Windows (SPSS, Inc., Chicago, IL, USA). $\mathrm{P}<0.05$ was considered to indicate a statistically significant difference.

\section{Results}

Effects of LEVA and GO on serum IFN- $\gamma, I L-5$ and TNF- $\alpha$ levels in Wistar rats. Treatment with LEVA elevated serum cytokine levels of IFN- $\gamma$, TNF- $\alpha$ and IL-5 to 5-, 4- and 2-fold that of the control, respectively. Treatment with GO elevated levels of IFN- $\gamma$ and TNF- $\alpha$ to 2- and 3-fold that of the control, respectively. In addition, $\mathrm{GO}$ induced a slight increase in IL-5 levels. Co-administration of GO and LEVA decreased LEVA-induced IFN- $\gamma$, TNF- $\alpha$ and IL-5 levels; however, GO and LEVA co-administration induced a 1.5-fold increase in serum IFN- $\gamma$ levels and a $\sim 3$-fold increase in serum TNF- $\alpha$ levels compared with the control group (Table II).

Effects of LEVA and GO on IgG and IgM levels in Wistar rats. Treatment with LEVA induced a 2-fold increase in $\mathrm{IgG}$ and IgM serum levels. In addition, GO administration induced a $\sim 60 \%$ elevation in IgG levels, but had no significant effects on IgM. Co-administration of LEVA and GO decreased LEVA-stimulated $\operatorname{IgG}$ and $\operatorname{IgM}$ levels, and returned them to normal (Table III).

Effects of LEVA and GO on red blood cell (RBC), white blood cell (WBC) and differential leukocyte count, and serum lysozyme activity in Wistar rats. Treatment with LEVA increased the number of total RBCs and WBCs, and various types of leukocytes compared with the control. GO administration increased the total WBC count and the various types of leukocytes compared with the control. Co-administration of LEVA and GO decreased LEVA-induced total WBC count and reduced the monocyte count. Lysozyme activity was increased in the LEVA treatment group and was higher than in the GO group. However, co-administration of LEVA and GO decreased LEVA-induced lysozyme activity (Table IV).

Effects of LEVA and GO on spleen immunohistochemical expression of CD4 and CD8 in Wistar rats. The spleen samples consisted of white pulp and red pulp surrounded by a connective tissue capsule. The white pulp consisted of circumscribed oval areas of B lymphocytes around a central vein. The central vein was surrounded by a periarterial lymphocytic sheath, which consisted of $\mathrm{T}$ lymphocytes. In addition, the white pulp contained a faint area called 
Table I. Polymerase chain reaction conditions and primer sequences of examined genes.

\begin{tabular}{|c|c|c|c|c|}
\hline Gene & Product size (bp) & Annealing $\left({ }^{\circ} \mathrm{C}\right)$ & Direction & Sequence $\left(5^{\prime}-3^{\prime}\right)$ \\
\hline IL-2 & 324 & 57 & $\begin{array}{l}\text { Forward } \\
\text { Reverse }\end{array}$ & $\begin{array}{c}\text { AAGGAAACACAGCAGCACCT } \\
\text { CACAGTTGCTGGCTCATCAT }\end{array}$ \\
\hline IL-4 & 327 & 57 & $\begin{array}{l}\text { Forward } \\
\text { Reverse }\end{array}$ & $\begin{array}{l}\text { AGGTCAACACCACGGAGAAC } \\
\text { AGGACATGGAAGTGCAGGAC }\end{array}$ \\
\hline IL-5 & 320 & 57 & $\begin{array}{l}\text { Forward } \\
\text { Reverse }\end{array}$ & $\begin{array}{l}\text { TGAGGATGCTTCTGTGCTTG } \\
\text { CCTCTCTTCGCCACACTTCT }\end{array}$ \\
\hline IL-12 $\alpha$ & 447 & 57 & $\begin{array}{l}\text { Forward } \\
\text { Reverse }\end{array}$ & $\begin{array}{l}\text { GCTTACCACTGGAACTCCACA } \\
\text { TCCTACAGGAGCTGAAGGTCA }\end{array}$ \\
\hline G3PDH & 309 & 52 & $\begin{array}{l}\text { Forward } \\
\text { Reverse }\end{array}$ & $\begin{array}{l}\text { AGATCCACAACGGATACATT } \\
\text { TCCCTCAAGATTGTCAGCAA }\end{array}$ \\
\hline
\end{tabular}

IL, interleukin; G3PDH, glyceraldehyde-3-phosphate dehydrogenase; bp, base pairs.

Table II. Serum changes in IFN- $\gamma$, IL-5 and TNF- $\alpha$ in Wistar rats following separate or combined administration of LEVA and GO for 4 weeks.

\begin{tabular}{lccc}
\hline Group & IFN- $\gamma(\mathrm{pg} / \mathrm{ml})$ & $\mathrm{IL}-5(\mathrm{pg} / \mathrm{ml})$ & $\mathrm{TNF}-\alpha(\mathrm{pg} / \mathrm{ml})$ \\
\hline Control & $22.9 \pm 2.7$ & $12.9 \pm 4.2$ & $9.1 \pm 1.6$ \\
LEVA & $117.7 \pm 14.1^{\mathrm{a}}$ & $22.6 \pm 0.8^{\mathrm{a}}$ & $36.4 \pm 2.8^{\mathrm{a}}$ \\
GO & $48.2 \pm 7.3^{\mathrm{a}, \mathrm{b}}$ & $14.5 \pm 3.01^{\mathrm{b}}$ & $26.4 \pm 2.9^{\mathrm{a}, \mathrm{b}}$ \\
LEVA + GO & $33.8 \pm 6.9^{\mathrm{b}}$ & $14.3 \pm 1.3^{\mathrm{b}}$ & $25.03 \pm 3.9^{\mathrm{a}, \mathrm{b}}$ \\
\hline
\end{tabular}

Values are presented as the mean \pm standard error of the mean for three independent experiments per treatment group. ${ }^{\mathrm{a}} \mathrm{P}<0.05$ vs. the control group; ${ }^{\text {P}}<<0.05$ vs. the LEVA group. IFN- $\gamma$, interferon- $\gamma$; IL, interleukin; TNF- $\alpha$, tumor necrosis factor- $\alpha$; LEVA, levamisole; GO, garlic oil.

Table III. Serum changes in immunoglobulin levels (IgG and $\operatorname{IgM})$ in Wistar rats after separate or combined administration of LEVA and GO for 4 weeks.

\begin{tabular}{lcc}
\hline Group & $\operatorname{IgG}(\mathrm{mg} / \mathrm{ml})$ & $\operatorname{IgM}(\mathrm{ng} / \mathrm{ml})$ \\
\hline Control & $1.8 \pm 0.2$ & $7.2 \pm 1.1$ \\
LEVA & $4.0 \pm 0.8^{\mathrm{a}}$ & $15.2 \pm 0.9^{\mathrm{a}}$ \\
GO & $3.0 \pm 0.3^{\mathrm{a}}$ & $8.6 \pm 1.5^{\mathrm{b}}$ \\
LEVA+GO & $2.2 \pm 0.1^{\mathrm{b}}$ & $5.5 \pm 1.1^{\mathrm{b}}$ \\
\hline
\end{tabular}

Values are presented as the mean \pm standard error mean for three independent experiments per treatment group. ${ }^{\mathrm{a}} \mathrm{P}<0.05 \mathrm{vs}$. the control group; ${ }^{b} \mathrm{P}<0.05$ vs. the LEVA group. Ig, immunoglobulin; LEVA, levamisole; GO, garlic oil.

the germinal center. The red pulp consisted of numerous B lymphocytes, plasma cells, macrophages and blood cells in the sinuses, which separated the white pulp from the red pulp (Fig. 1A). The immunohistochemical expression of CD4 in the lymphocytes of the control group was positive (Fig. 1B); however, the immunoreactivity was stronger in the LEVA group (Fig. 1C). The expression was diminished in the GO group compared with the LEVA group (Fig. 1D), and the levels returned to control levels in the LEVA and GO co-treated rats (Fig. 1E). The immunohistochemical expression of CD8 was positive in the spleen of the control group (Fig. 1F), and was increased in the LEVA group (Fig. 1G). CD8 expression was decreased in the GO group (Fig. 1H). In addition, in the LEVA plus GO group the expression of CD8 almost returned to control levels (Fig. 1J).

Effects of LEVA and GO on the mRNA expression levels of $I L-2, I L-4$ and IL5 in rat leukocytes. The mRNA expression levels of the cytokines IL-2, IL-4 and IL-5 were upregulated in rat leukocytes (3-, 6- and 9-folds, respectively) in the LEVA group compared with the control group. In addition, GO administration downregulated the expression levels of IL-2, IL-4 and IL-5 compared with the control group. Co-administration of LEVA and GO decreased the expression of the examined cytokines by $50 \%$ compared with in the LEVA group (Fig. 2).

Effects of LEVA and GO on the mRNA expression levels of $I L-4, I L-5$ and $I L-12$ in the thymus gland of rats. The mRNA expression levels of IL-4 were increased by 7-fold in the thymus of the LEVA group compared with the control group, and were also increased, but to a lesser extent, in the GO group. Co-administration of LEVA and GO decreased IL-4 gene expression to $20 \%$ that in the LEVA-treated group (Fig. 3). IL-5 mRNA expression was upregulated in the LEVA 

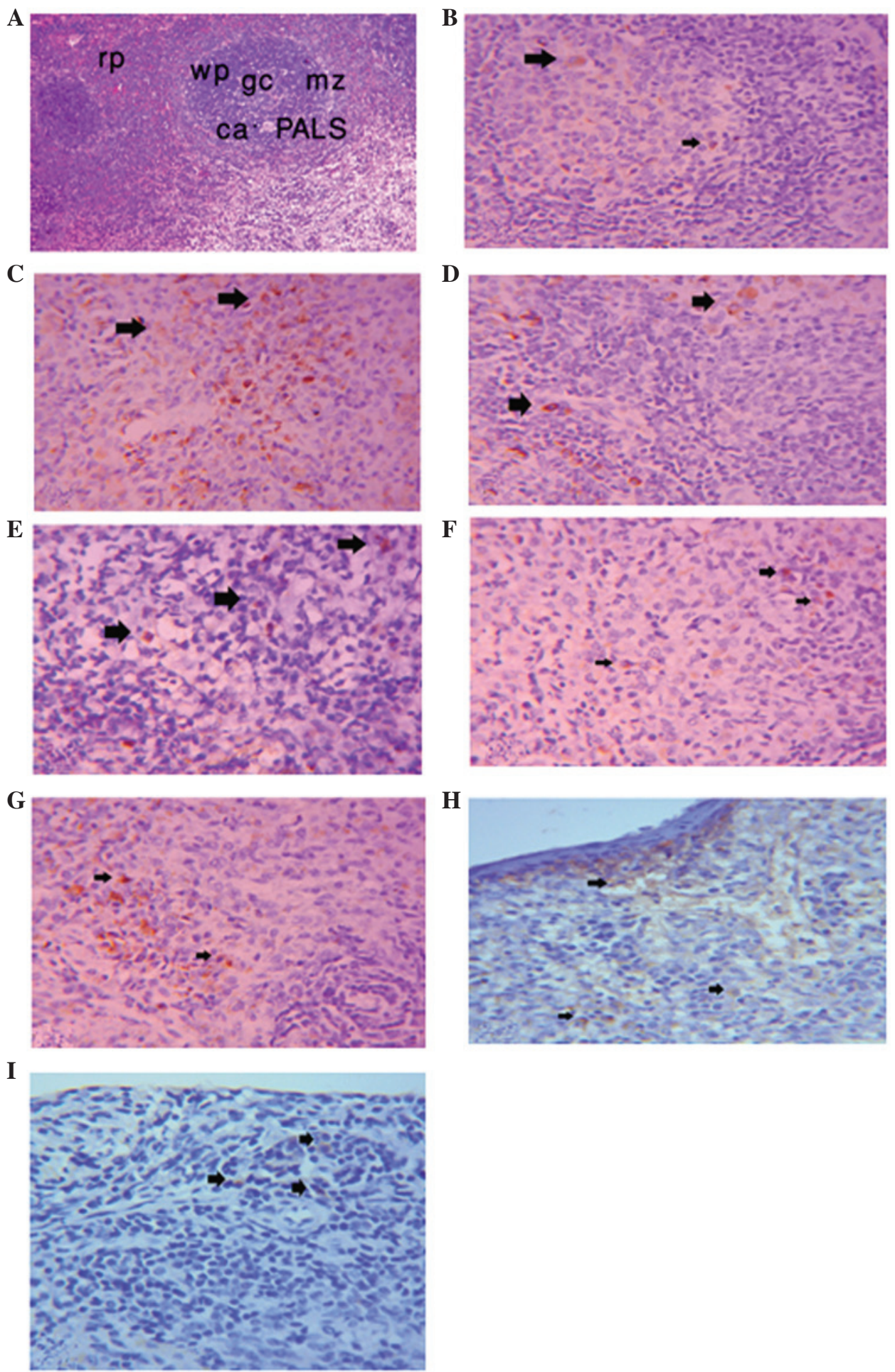

Figure 1. CD4 expression in the spleen. Photomicrograph of the spleen in male rats showing (A) white pulp (wp), red pulp (rp), germinal center (gc), marginal zone (mz), central artery (ca) and periarterial lymphocytic sheath (PALS). Hematoxylin \& eosin staining; magnification, x10. (B) Immunohistochemical expression of CD4 in lymphocyte cells of the spleen of the control group (as indicated by arrows; magnification, x10). (C) Immunohistochemical expression of CD4 in lymphocyte cells of the spleen of the levamisole (LEVA) group (as indicated by arrows; magnification, x10). (D) Immunohistochemical expression of CD4 in lymphocyte cells of the spleen of the garlic oil (GO) group (as indicated by arrows; magnification, x10). (E) Immunohistochemical expression of CD4 in lymphocyte cells of the spleen of the LEVA plus GO group (as indicated by arrows; magnification, x10). (F) Immunohistochemical expression of CD8 in lymphocyte cells of the spleen of the control group (as indicated by arrows; magnification, x10). (G) Immunohistochemical expression of CD8 in lymphocyte cells of the spleen of the LEVA group (as indicated by arrows; magnification, x10). (H) Immunohistochemical expression of CD8 in lymphocyte cells of the spleen of the GO group (as indicated by arrows; magnification, x10). (I) Immunohistochemical expression of CD8 in lymphocyte cells of the spleen of the LEVA plus GO group (as indicated by arrows; magnification, $\mathrm{x} 10$ ).

and GO groups compared with the control. Co-administration of LEVA and GO exhibited an additive regulatory effect on IL-5 expression (Fig. 3). IL-12 $\alpha$ mRNA expression was not affected by LEVA treatment alone; however, it was upregulated following GO treatment alone or in combination with LEVA, compared with the control group (Fig 3). 
Table IV. Changes in RBC count, total WBC count and leukocyte types, and serum lysozyme activity in Wistar rats after separate or combined administration of LEVA and GO for 4 weeks.

\begin{tabular}{lcccc}
\hline Cell type & Control & LEVA & GO & LEVA+GO \\
\hline WBCs $\left(\times 10^{3} / \mu 1\right)$ & $10.2 \pm 1.75$ & $12.07 \pm 0.63^{\mathrm{a}}$ & $10.7 \pm 0.62^{\mathrm{b}}$ & $9.82 \pm 0.10^{\mathrm{c}}$ \\
Neutrophils $\left(\mathrm{x} 10^{3} / \mu \mathrm{l}\right)$ & $2.32 \pm 0.31$ & $3.303 \pm 0.29^{\mathrm{a}}$ & $2.58 \pm 0.18^{\mathrm{b}}$ & $2.25 \pm 0.27^{\mathrm{c}}$ \\
Lymphocytes $\left(\mathrm{x} 10^{3} / \mu \mathrm{l}\right)$ & $7.5 \pm 0.35076$ & $8.7 \pm 0.87^{\mathrm{a}}$ & $8.7 \pm 0.75^{\mathrm{b}}$ & $7.29 \pm 0.13^{\mathrm{c}}$ \\
Monocytes $\left(\mathrm{x} 10^{3} / \mu \mathrm{l}\right)$ & $0.9 \pm 0.09$ & $1.12 \pm 0.10^{\mathrm{a}}$ & $1.01 \pm 0.16^{\mathrm{b}}$ & $0.2 \pm 0.09^{\mathrm{c}}$ \\
Eosinophils $\left(\mathrm{x} 10^{3} / \mu \mathrm{l}\right)$ & $0.2 \pm 0.15$ & $0.33 \pm 0.035^{\mathrm{a}}$ & $0.23 \pm 0.005^{\mathrm{b}}$ & $0.37 \pm 0.18^{\mathrm{c}}$ \\
Basophils $\left(\mathrm{x} 10^{3} / \mu \mathrm{l}\right)$ & $0.02 \pm 0.0006$ & $0.18 \pm 0.23^{\mathrm{a}}$ & $0.03 \pm 0.005^{\mathrm{b}}$ & $0.023 \pm 0.01^{\mathrm{c}}$ \\
RBCs $\left(\mathrm{x} 10^{6} / \mu \mathrm{l}\right)$ & $8.9 \pm 0.17$ & $9.4 \pm 0.31^{\mathrm{a}}$ & $9.01 \pm 1.38^{\mathrm{b}}$ & $9.5 \pm 0.5^{\mathrm{c}}$ \\
Lysozyme activity & $255.3 \pm 19.5$ & $387.3 \pm 23.6^{\mathrm{a}}$ & $303.2 \pm 19.3^{\mathrm{a}}$ & $217.6 \pm 21.2^{\mathrm{a}}$ \\
\hline
\end{tabular}

Values are presented as the mean \pm standard error of the mean for three independent experiments per treatment group. ${ }^{\mathrm{a}} \mathrm{P}<0.05$ vs. the control group; ${ }^{\mathrm{b}}<0.05$ vs. the LEVA group and ${ }^{\mathrm{c}} \mathrm{P}<0.05$ vs. both LEVA and $\mathrm{GO}$ groups.
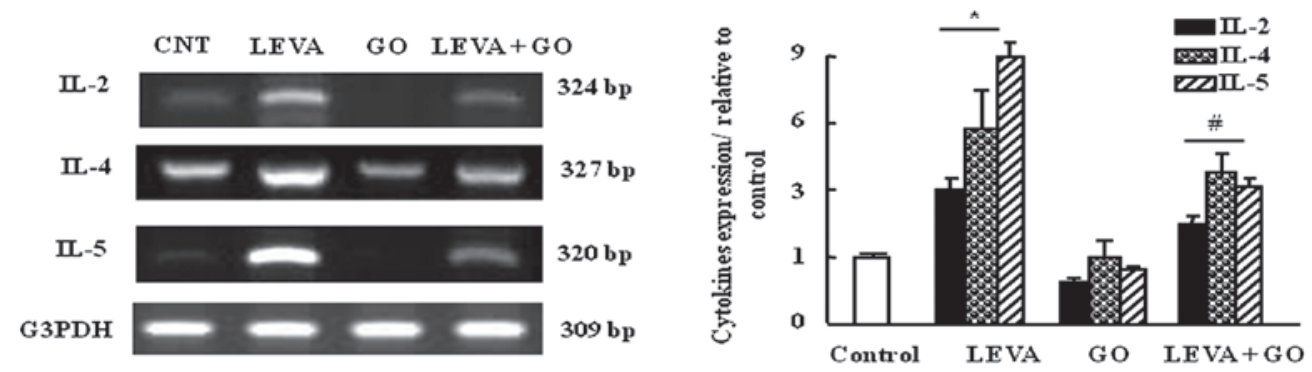

Figure 2. Semi-quantitative reverse transcription polymerase chain reaction (RT-PCR) analysis was used to detect the mRNA expression levels of interleukin (IL)-2, IL-4 and IL-5, and glyceraldehyde 3-phosphate dehydrogenase (G3PDH) in leukocytes. Experimental groups were administered vehicle as a control, levamisole (LEVA), garlic oil (GO), or LEVA plus GO. RNA was extracted and reverse transcribed ( $3 \mu \mathrm{g})$, and RT-PCR analysis was carried out for the indicated genes. Densitometric analysis was carried out for five different rats from each group. Values are presented as the mean \pm standard error of the mean obtained from six rats per group. " $\mathrm{P}<0.05$ vs. the control group, and ${ }^{\#} \mathrm{P}<0.05$ vs. the LEVA group. bp, base pairs.
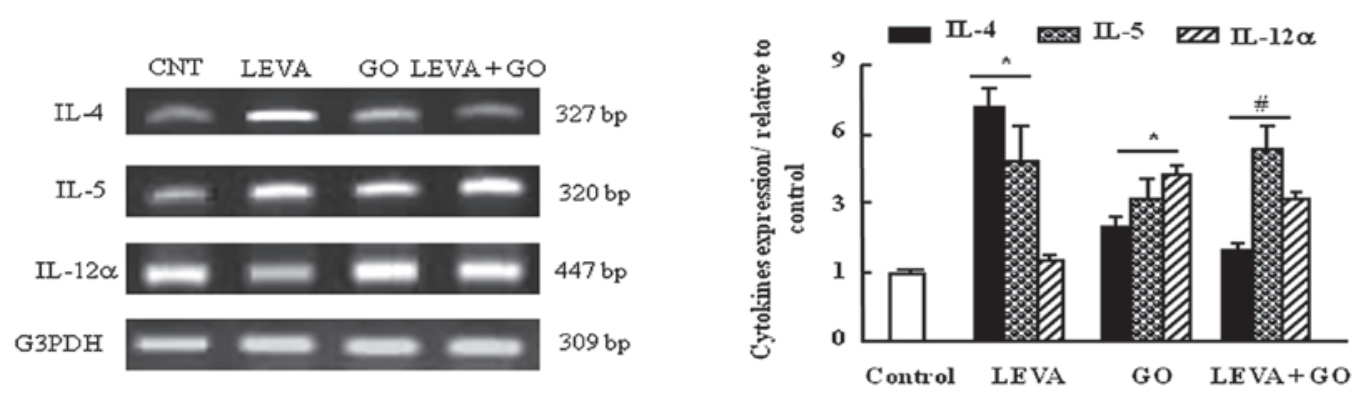

Figure 3. Semi-quantitative reverse transcription polymerase chain reaction (RT-PCR) analysis was used to detect the mRNA expression levels of interleukin (IL)-4, IL-5 and IL-12 $\alpha$, and glyceraldehyde 3-phosphate dehydrogenase (G3PDH) in the thymus. Experimental groups were administered corn oil as a control, levamisole (LEVA), garlic oil (GO), or LEVA plus GO. RNA was extracted and reverse transcribed ( $3 \mu \mathrm{g})$, and RT-PCR analysis was carried out for the indicated genes. Densitometric analysis was carried out for five different rats from each group. Values are presented as the mean \pm standard error of the mean obtained from six rats per group. ${ }^{*} \mathrm{P}<0.05$ vs. the control group, and ${ }^{\#} \mathrm{P}<0.05$ vs. the LEVA group. bp, base pairs.

\section{Discussion}

The results of the present study demonstrated thatLEVA and GO can modulate the immune response in rats. Co-administration of LEVA and GO modulated the rats' immune response towards a Th1/Th2 balance; therefore, maintaining the body's defensive mechanisms within normal ranges.

IFN- $\gamma$ is an essential cytokine for immunity against intracellular pathogens and cancer (23). Targeted disruptions of the IFN- $\gamma$ gene or IFN- $\gamma$ receptor 1 gene in mice render them highly susceptible to bacterial, protozoan and viral infections (24). The role of IFN- $\gamma$ in CD8 T cell cellular immunity is to enhance the major histocompatibility complex class I antigen presentation pathway, which facilitates cytotoxic $\mathrm{T}$ cells to recognize infected cells (23). In the present study, the elevated levels of IFN- $\gamma$ detected following LEVA treatment indicated its immunostimulatory effect towards induction and activation of Th1 cells, as reported in a previous 
study (12). The reduction of LEVA-elevated serum IFN- $\gamma$ levels by $\mathrm{GO}$ administration indicated the balancing effect of GO against immune deviation. Autoimmune and inflammatory diseases may be associated with a Th1/Th2 bias. For example, insulin-dependent diabetes mellitus (type 1 diabetes) (25) features a predominant Th1 response, whereas asthma is characterized by a predominant Th2 response (26). The induction of TNF- $\alpha$ with either LEVA or GO suggested that these two agents have a macrophage stimulatory effect. Recently, garlic extract has been reported to exert a stimulatory effect on TNF- $\alpha$ gene expression in murine macrophages (27). However, in the combined group in the present study, GO reduced LEVA-induced serum TNF- $\alpha$ elevation, thus implying that GO has a stimulatory effect on basal macrophage activity, which is concordant with the results of a previous study (28).IL-5 has a central role not only in the stimulation of B-cell growth and Ig production, but also in the production, mobilization, activation, recruitment, proliferation and survival of eosinophils at the site of inflammation $(29,30)$. The downregulating effect of GO on LEVA-induced serum IL-5 levels and gene expression in circulating leukocytes and the thymus is concordant with its recently reported anti-allergic effects (31). LEVA-induced IgG and IgM elevation provided evidence for the immunostimulatory effect of LEVA, and is in agreement with its effect on calves (32). The normalizing effects of GO on LEVA-induced IgG and IgM elevation indicated its immunomodulatory effect, and is in agreement with its lowering effect on $\operatorname{IgG}$ and $\operatorname{IgM}$ in human patients (33).

The effects of LEVA on the upregulation of peripheral leukocytes is in line with its effects on serum cytokine and Ig levels, and coincided with its effect in rats (34). The lowering effect of GO on the LEVA-induced upregulation of circulating leukocytes may be attributed to its major sulfur component, diallyl disulfide, which has been reported to decrease the number of circulating cells, particularly lymphocytes, eosinophils and monocytes (35).

Lysozyme enzymes are required for antigen presentation by $\mathrm{T}$ cells, and the removal of tumor cells and infected cells by cytotoxic T lymphocytes (36). Therefore the LEVA-induced upregulation of lysozyme activity is consistent with its immunostimulatory effect. In addition, prolonged use of proton pump inhibitors (PPI) has been associated with the development of gastric neuroendocrine carcinoma (37), which has recently been attributed to the inhibitory effects of PPI on lysozyme enzyme activity and may result in immunosuppression (36). The stimulatory effect of GO on lysozyme activity when administered alone, and its inhibitory effect when administered with LEVA, indicated that GO has an immunomodulatory balancing effect, which may counteract any immune system deviation. The effects of GO on reduction of lysozyme activity may be attributed to the inhibitory effects of allicin, a constituent of GO (38).

LEVA-induced elevation of the $\mathrm{CD}^{+}{ }^{+}$population in the spleen is consistent with its elevating effect on the number of circulating lymphocytes, serum Igs and cytokine levels. CD4 ${ }^{+}$ cells have been reported to be increased in response to LEVA used as an adjuvant to hepatitis B vaccine in patients with human immunodeficiency virus/acquired immune deficiency syndrome (39). The administration of LEVA in children with malnutrition, has also been reported to increase the mean CD4 count by $20 \%$ (40). These results indicated that LEVA may augment the ability of $\mathrm{B}$ cells to produce antibodies through increasing the $\mathrm{CD}^{+}$population (41). The GO-induced reduction in the $\mathrm{CD}^{+}$population may indicate its balancing effect on the immune reaction; lowering $\mathrm{B}$ cell activation and antibody production, particularly when B cells are highly activated. This effect may be attributed to the presence of diallyl trisulfide in $\mathrm{GO}$, which has been reported to exert anti-inflammatory effects and reduce lipopolysaccharide-induced IL-6, IL-12 and TNF- $\alpha$ (42).

The upregulatory effect of LEVA on the population of $\mathrm{CD}^{+}$cells in the thymus and spleen modulated the cytotoxic cell response through the modulation of cytokine expression and secretion. In the present study, GO increased IL-12 expression, which is known to mediate the $\mathrm{CD}^{+}$cytotoxic resopnse; however, in the present study GO decreased the CD8 cytotoxic response. Conversely, LEVA alone did not alter IL-12 $\alpha$ gene expression; however, when co-administered with GO, LEVA induced partial suppression of GO-induced IL-12 $\alpha$ gene expression. In addition, human conventional myeloid dendritic cells have been described to be the most potent producers of bioactive IL-12, which can promote cytotoxic $\mathrm{CD}^{+} \mathrm{T}$-cell responses (43). The LEVA-induced suppression of GO-induced IL-12 $\alpha$ detected in the present study is in accordance with a previous report indicating LEVA-induced suppression of IL-12 $\alpha$ gene expression after 3 days administration in rats (12). Furthermore, the induction of IL-12 $\alpha$ gene expression following GO administration is in concordance with the previously reported activation of IL-12 using garlic extract (44). These effects may be mediated by garlic protein, which has been reported to augment $\mathrm{CD} 8^{+} \mathrm{T}$-cell infiltration into the tumor site and inhibit tumor growth (8).

IL-4 stimulates the differentiation of naïve helper $\mathrm{T}$ cells (Th0 cells) to Th 2 cells. Upon activation by IL-4, Th2 cells subsequently produce additional IL-4 in a positive feedback loop. IL-4 expression is upregulated in hypersensitive immune responses and allergies (45). The suppressive effect of GO on the LEVA-induced upregulation of IL-4 indicates the anti-allergic effects of GO. These results are consistent with those of a previous study that revealed the anti-allergic effects of garlic extract (31). IL-2 supports the growth and expansion of B cells, as well as other immune cells, such as $\mathrm{T}$ cells, at varying stages of development or activation (46). In the present study, LEVA induced-IL-2 expression as it stimulated the immune system towards a type 1 response, and GO downregulated the expression of IL-2, which is consistent with its lowering effects on serum Ig and cytokine levels, and is in accordance with previously reported data when both LEVA and $\mathrm{GO}$ are administered (47).

In conclusion, the present study demonstrated that LEVA acts by directing the immune balance towards a type 1 response via induction of Th1 activation and upregulation of IL-2, IL-4, IL-5, IFN- $\gamma$, TNF- $\alpha$ and IL-12. Treatment with GO was shown to direct the immune response towards the induction and activation of $\mathrm{Th} 2$, thus increasing humoral immunity against extracellular microorganisms. The combination of LEVA and GO acted in a countercurrent manner to maintain the Th1/Th2 balance and enforce the body defensive mechanism. The present study provided a novel perspective for the use of medicinal plants as adjuvant therapy, which may be added to 
food to prevent disease. Further in vitro studies focusing on the mechanism of action of $\mathrm{GO}$ are required.

\section{References}

1. Page DB, Postow MA, Callahan MK, Allison JP and Wolchok JD Immune modulation in cancer with antibodies. Annual Review Med 65: 185-202, 2014

2. Agrawal SS, Khadase SC and Talele GS: Studies on immunomodulatory activity of Capparis zeylanica leaf extracts. International Journal of Pharmaceutical Sciences and Nanotechnology 3: 887-892, 2010.

3. Kandil OM, Abdellah TH and Elkadi A: Garlic and the immune system in humans: Its effects on natural killer cells. Federal Procedures 46: 441, 1987 .

4. Butt MS, Sultan MT, Butt MS and Iqbal J: Garlic nature's protection against physiological threats. Crit Rev Sci Nutr 49: 538-551, 2009.

5. Kyo E, Uda N, Suzuki A, Kakimoto M, Ushijima M, Kasuga S and Itakura Y: Immunomodulatory effects of aged garlic extract. J Nutr 131: 1075S-1079S, 2001

6. Ghazanfari T, Hassan ZM, Ebtekar M, Ahmadiani A, Naderi G and Azar A: Garlic induces a shift in cytokine pattern in leishmania major-infected BALB/c mice. Scand J Immunol 52: 491-495, 2000

7. Chandrashekar PM and Venkatesh YP: Identification of the protein components displaying immunomodulatory activity in aged garlic extract. J Ethnopharmacolol 124: 384-390, 2009.

8. Ebrahimi M, Mohammad Hassan Z, Mostafaie A, Zare Mehrjardi N and Ghazanfari T: Purified protein fraction of garlic extract modulates cellular immune response against breast transplanted tumors in BALB/c mice model. Cell J 15: 65-75, 2013.

9. Chadwick RG, Jain S, Cohen BJ, Scott GM, Thomas HC and Sherlock S: Levamisole therapy for HbsAg-positive chronic liver disease. Scand J Gastroenterol 15: 973-978, 1980

10. Fox MT, Jacobs DE, Campling RC, Pocknee BR, Clampitt R and Hart IC: Effect of thiabendazole treatment on feed intake, digetability and selected blood values in lactating dairy cows. Vet Rec 116: 257-260, 1985.

11. Mitchell MS: Immunotherapy as part of combinations for the treatment of cancer. Int Immunopharmacol 3: 1051-1059, 2003.

12. Szeto C, Gillespie KM and Mathieson PW: Levamisole induces interleukin-18 and shifts type 1/type 2 cytokine balance. Immunology 100: 217-224, 2000.

13. Olusi SO, Jessop WJE and Shoroye A: Effects of levamisole on the immune response of experimentally malnourished rats. Pediatric Res 13: 1237-1239, 1979.

14. Kocabas CN, Sekerel BE, Firat PA, Okur H and Adahoglu G: Levamisole: Might it be used in treatment and prevention of atopic diseases? J Asthma 41: 547-551, 2004.

15. Chen LY, Lin YL and Chiang BL: Levamisole enhances immune response by affecting the activation and maturation of human monocyte-derived dendritic cells. Clin Exp Immunol 151: 174-181, 2008

16. Mulero V, Esteban MA, Munxoz J and Meseguer J: Dietary intake of levamisole enhances the immune response and disease resistance of the marine teleost gilthead seabream (Sparus aurata L). Fish and Shellfish Immunology 8: 49-62, 1998.

17. Ali HS, El-Sanosi YA and Shaimaa A: Biochemical, immunomodulatory and antioxidant proportes of levamisole at different storage conditions and administration routes. Pak J Biol Sci 15 986-991, 2012.

18. Hassan HA, Hafez HS and Zeghebar FE: Garlic oil as a modulating agent for oxidative stress and neurotoxicity induced by sodium nitrite in male albino rats. Food Chem Toxicol 48 1980-1985, 2010.

19. Osserman EF and Lawlor DP: Serum and urinary lysozyme (muramidase) in monocytic and monomyelocytic leukemia. J Exp Med 124: 921-952, 1966.

20. Bancroft JD and Gamble M: Theory and practice of histological techniques. 6th ed. Churchill Livingstone Elsevier Philadelphia: 126-127, 2008

21. Cho Y, Miyamoto M, Kato K, Fukunaga A, Shichinohe T, Kawarada Y, Hida Y, Oshikiri T, Kurokawa T, Suzuoki M, et al: CD4+ and CD8+ T cells cooperate to improve prognosis of patients with esophageal squamous cell carcinoma. Cancer Res 63: 1555-1559, 2003
22. Soliman MM, Nassan MA and Ismail TA: Immunohistochemical and molecular study on the protective effect of curcumin against hepatic toxicity induced by paracetamol in Wistar rats. BMC Complement Altern Med 14: 457, 2014

23. De Araújo-Souza PS, Hanschke SC and Viola JPJ: Epigenetic control of interferon-gamma expression in CD8 T cells. J Immunol Res 2015: 849573, 2015.

24. SchroderK,Hertzog PJ,Ravasi Tand Hume DA:Interferon-gamma: An overview of signals, mechanisms and functions. J Leukoc Biol 75: 163-189, 2004.

25. Heurtier AH and Boitard C: T-cell regulation in murine and human autoimmune diabetes: The role of TH1 and TH2 cells. Diabetes Metab 23: 377-385, 1997

26. Kay AB: TH2-type cytokines in asthma. Ann N Y Acad Sci 796: $1-8,1996$

27. Sung J, Harfouche Y, De La Cruz M, Zamora MP, Liu Y, Rego JA and Buckley NE: Garlic (Allium sativum) stimulates lipopolysaccharide-induced tumor necrosis factor-alpha production from J774A.1 murine macrophages. Phytother Res 29: 288-294, 2015.

28. Nair P: What is an 'eosinophilic phenotype' of asthma? J Allergy Clin Immunol 132: 81-83, 2013.

29. Gleich GJ: Mechanisms of eosinophil-associated inflammation. J Allergy Clin Immuol 105: 651-663, 2000.

30. Garcia G, Taillé C, Laveneziana P, Bourdin A, Chanez P and Humbert M: Antiinterleukin-5 therapy in severe asthma. Eur Respir Rev 22: 251-257, 2013.

31. Yoo JM, Sok DE and Kim MR: Anti-allergic action of aged black garlic extract in RBL-2H3 cells and passive cutaneous anaphylaxis reaction in mice. J Med Food 17: 92-102, 2014

32. Pekmezci D and Cakiroglu D: Investigation of immunmodulatory effects of levamisole and vitamin $\mathrm{E}$ on immunity and some blood parameters in newborn Jersey calves. Vet Res Commun 33: 711-721, 2009.

33. Budoff MJ, Ahmadi N, Gul KM, Liu ST, Flores FR, Tiano J, Takasu J, Miller E and Tsimikas S: Aged garlic extract supplemented with B vitamins, folic acid and L-arginine retards the progression of subclinical atherosclerosis: A randomized clinical trial. Prev Med 49: 101-107, 2009.

34. Chekwube AI, Onyema EI, Ikenna UE and Ezeokonkwo RC: Effect of diminazene aceturate, levamisole and vitamin $\mathrm{C}$ combination therapy in rats experimentally infected with Trypanosoma brucei brucei. Asian Pac Trop Med 7: 438-445, 2014.

35. Diegane N Dong and Jean Fall: The effect of garlic (Allium sativum) on growth and immune responses of hybrid tilapia (Oreochromis niloticus x Oreochromis aureus. Journal of Clinical Immnunology and Immunopathology Research Vol 3: 1-9, 2011.

36. Jollès P and Jollès J: What's new in lysozyme research? Always a model system, today as yeas day. Mol Cell Biochem 63: 165-189. Jorgensen J, Robertsen B (1995). Yeast_-glucan stimulates respiratory burst activity of Atlantic salmon (Salmo salar L.) macrophages. Dev Comp Immunol 19: 43-157, 1984.

37. Jianu CS, Lange OJ, Viset T, Qvigstad G, Martinsen TC, Fougner R, Kleveland PM, Fossmark R, Hauso $\varnothing$ and Waldum HL: Gastric neuroendocrine carcinoma after long-term use of proton pump inhibitor. Scan J Gastroenterol 47: 64-67, 2012.

38. Mayeux PR, Agrawal KC, Tou JS, King BT, Lippton HL, Hyman AL, Kadowitz PJ and McNamara DB: The pharmacological effects of allicin, a constituent of garlic oil. Agents Actions 25: 182-190, 1988

39. Sayad B, Alavian SM, Najafi F, Soltani B, Shirvani M, Janbakhsh A, Mansouri F, Afsharian M, Vaziri S, Alikhani A and Bashiri H: Effects of Oral Levamisole as an adjuvant to hepatitis B vaccine in HIV/AIDS patients: A randomized controlled trial. Hepat Mon 12: e6234, 2012.

40. Prakash MS, Rao VM and Reddy V: Effect of levamisole on the immune status of malnourished children. J Trop Pediatr 44: 165-166, 1998.

41. Cantor HEA and Boyse: Regulation of cellular and humoral immune responses by T-cell subclasses. Cold Spring Harb Symp Quant Biol 41: 23-32, 1977.

42. You S, Nakanishi E, Kuwata H, Chen J, Nakasone Y, He X, He J, Liu X, Zhang S, Zhang B and Hou DX: Inhibitory effects and molecular mechanisms of garlic organosulfur compounds on the production of inflammatory mediators. Mol Nutr Food Res 57: 2049-2060, 2013

43. Nizzoli G1, Krietsch J, Weick A, Steinfelder S, Facciotti F, Gruarin P, Bianco A, Steckel B, Moro M, Crosti M, et al: Human CD1c+ dendritic cells secrete high levels of IL-12 and potently prime cytotoxic T-cell responses. Blood 122: 932-942, 2013 
44. Gharavi M, Nobakht $M$, Khademvatan S, Fani F, Bakhshayesh M and Roozbehani M: The Effect of aqueous garlic extract on interleukin-12 and 10 levels in leishmania major (MRHO/IR/75/ER) infected macrophages. Iran J Public Health 40: 105-111, 2011.

45. Burton OT, Darling AR, Zhou JS, Noval-Rivas M, Jones TG, Gurish MF, Chatila TA and Oettgen HC: Direct effects of IL-4 on mast cells drive their intestinal expansion and increase susceptibility to anaphylaxis in a murine model of food allergy. Mucosal Immunol 6: 740-750, 2013.
46. Liao W, Lin JX and Leonard WJ: Interleukin-2 at the crossroads of effector responses, tolerance and immunotherapy. Immunity 38: 13-25, 2013.

47. Mantawy MM, Ali HF and Rizk MZ: Therapeutic effects of Allium sativum and Allium cepa in Schistosoma mansoni experimental infection. Revista Inst Med Trop Sao Paulo 53: 155-163, 2011. 